\title{
The Effectiveness of Entrepreneurship Management on the Mosque Prosperity Agency in Langsa in the terms of Sharia
}

\author{
Zulkarnen Mora', Dias Setianingsih ${ }^{2}$, Bustami $^{3}$ \\ ${ }^{1,2}$ Faculty of Economics, Universitas Samudra, Indonesia \\ ${ }^{3}$ Faculty of Law, Universitas Samudra, Indonesia \\ zulkarnen.mora@unsam.ac.id
}

\begin{abstract}
The Mosque Prosperity Body (BKM) has a central role in managing the economy of people who practice worship as a goal of life in kafah. In Islam itself, welfare is a major milestone in the implementation of Muslim worship. The purpose of this study is to measure the extent to which the effectiveness of entrepreneurship management carried out by BKM in Langsa City in terms of sharia. This research is an exploratory research with a qualitative approach. The sample was selected based on the division of regions, namely 1 Langsa Municipality (BKM Darul Falah) and 5 sub-districts in the Langsa City area which consists of 5 districts, namely East Langsa (BKM Nurul Quran), Langsa Lama (BKM Nurul Iman), Langsa Kota (BKM Taqwa) ), Langsa Baro (BKM Baitul Mukmin), and Langsa Barat (BKM Baitul Aminin). The sample was selected based on the determination of aspects of the application of Idarah (management), Imarah (prosperity) and Ri'ayah (facilities and care). The stages of the research method began with observation, identification, literature review, data collection, designing research instruments, Focus Group Discussion (FGD), data analysis and formulation of research results. The output of this research is targeted to be an article published in an accredited journal 3. In addition, the Technology Readiness Level where the results of this study are expected to become a role model for the application of measuring the effectiveness of entrepreneurial management based on sharia reviews in every mosque prosperity body in Langsa City and Aceh region. and Indonesia in general. Thus the role and function of the mosque prosperity body is increasingly contributive and measured in carrying out its work as a Muslim socio-economic institution with the aim of providing welfare values so that it is more aspirational, of course, even though the results of the research obtained have not met expectations / the implementation of entrepreneurial management at BKM in Langsa City has not been effective. In terms of its imarah function, however, other functions such as idarah and ri'ayah have met the standard criteria.
\end{abstract}

Keywords

entrepreneurship, mosque prosperity agency, idarah; imarah; ri'ayah



\section{Introduction}

Aceh Province is one of the provinces in Indonesia which has the privilege of having a majority of the people who are Muslim and apply the concept of Islamic law. Previously this province was called the Special Region of Aceh. These features are still visible until now, namely the government is granted especially through the Aceh Government Act, one of which is that it can be fully enforced (kaffah) in accordance with the ideals of the Acehnese people. The government and the people of Aceh jointly uphold and implement Islamic law. 
Another regulation is the establishment of Qanuns / regional regulations to support the implementation of Islamic law in Aceh. Islamic syari'at is the guidance of Islamic teachings in all aspects of life. The implementation of Islamic Shari'at is regulated in the Regional Regulation of the Special Region of Aceh Province number 5 of 2000 concerning the Implementation of Islamic Shari'at (Dinas Syari'at Islam, 2009: 257). The existence of mosques that are often found in Aceh province has a strategic role in economic development. With the presence of a Mosque Information System (SIMAS), anyone connected to the internet can find out the profile and history of mosques, data of mosque administrators and imams, study schedules and mosque Friday preachers equipped with photographs and locations of mosques throughout Indonesia.

Among the Qanuns that were built was Nanggroe Aceh Darussalam Province Qanun Number 12 of 2003 concerning khamar drinks and other form, Qanun Number 13 of 2003 about maisir (gambling), and Qanun Number 14 of 2003 about khalwat (nasty). The essence of the three Qanun is to prohibit the consumption of liquor, gambling and nasty. In addition, it also stipulates sanctions in the form of caning of the perpetrators. (Helmi, 2019).

Social enterprises are productive structures that have an imprint of social benefit and, in this sense, it can be affirmed that they are alternative forms of companies within a neoliberal capitalism, which houses organizations oriented to profit, capital accumulation and enrichment of few people, contributing to the polarization between the city and the countryside. (Lendechy, 2019).

The mosque is not only a center of spiritual worship, but in essence the function of a mosque can also be a place to strengthen social relations between fellow humans and as a place to develop friendship to exchange ideas, share experiences and information, solve various problems from the development of human civilization. Mosques also play a role in solving educational, socio-cultural, social and especially socio-economic problems. The challenges for the Aceh economy until 2019 are still faced with problems of income inequality, poverty and the unemployment rate. This has had a huge impact on the community and especially the congregation of mosques in Aceh. Some of the congregation who expect him to be able to entrust their capital and shares for the economic empowerment of the mosque as a means of preaching activities that transcend boundaries of ethnicity, culture, and social background (Dalmeri, 2014). According to Simas data there are around 4315 mosques and 7336 in Aceh and, in the city of Langsa there are 66 mosques 302 musholla (simas.kemenag.co.id).

Referring to the data above, especially in the city of Langsa, there are several mosques that embody the community's activities into a Mosque Prosperity Body (BKM). The goal is that the congregation can take advantage of the available resources to achieve a level of prosperity both in the world and in the hereafter through studies of Islamic education, Islamic civilization and the socio-economic and welfare of the ummah. In Islam itself, welfare and the principle of justice are the main milestones in the implementation of Muslim worship. Thus, in order for the implementation of worship to be more solemn, it is necessary to ensure that the two principles, namely welfare and justice, are effectively facilitated by BKM.

According to the Decree of the Director General of Islamic Community Guidance Number DJ.II / 802 of 2014 concerning Standards for Mosque Management Guidance, the typology of mosques is divided into state mosques which are located in the national capital, the national mosque is located in the provincial capital, and the grand mosque is located in the capital. Regency / city cities, large mosques located in sub-districts and Jami mosques located in residential centers in rural areas as well as historic mosques domiciled in historic areas, mosques in public places isolated in public areas. 
Meanwhile, the standardization of all mosques is viewed from the typology aspect and its development is based on the functions of idarah (management), imarah (prosperity) and ri'ayah (maintenance and provision of facilities).

Judging from the definition, the Idarah function is a management activity that involves planning, organizing, administering, finance, monitoring and reporting. Furthermore, the function of imarah includes activities to prosper the mosque such as worship, education, social activities (sharia economy, culture and religion) and commemoration of Islamic holidays. Finally, the function of ri'ayah includes building maintenance, equipment, environmental cleanliness, beauty and security of the mosque, including determining the direction of the Qibla. (Attachment to Kep. Director General of Islamic Community Guidance No. DJ.II / 802/2014).

Based on the foregoing, especially regarding the three functions, especially those covering the field of direction which describes social activities where the emphasis is on the entrepreneurial aspect as part of Islamic economics carried out by BKM in Langsa City today. Referring to the Word of Allah in surah Al-Jum'ah verse 11:

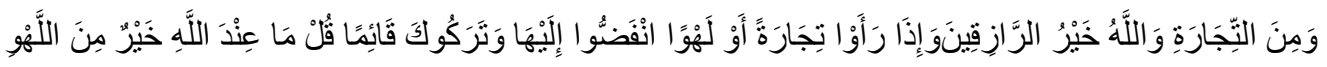

Meaning: "And when they see a trade or a game, they immediately go to him and they stay you (Muhammad) standing (preaching). Say," What is with Allah is better than games and commerce, "and Allah provides the best sustenance."

The words of the Prophet Muhammad S.A.W.

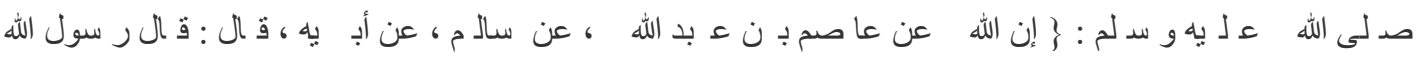



$$
\begin{aligned}
& \text { رواية ة اب ن ع بدان }
\end{aligned}
$$

Meaning: From Ashim bin Ubaidillah, from Salim, from his father, he said, Rasulullah SAW. Has said "verily Allah loves a believer who works / works hard." And in the history of Ibn Abdan, "a young man who works / works hard." (H.R. Baihaqy).

By referring to the two sources of the quotation above, it is clear to us that entrepreneurial management which is managed by believers is very important, especially through increasing business interest and motivation influencing the success of their business as has been shown by young entrepreneurs of Kota Langsa (Ardiyanti and Mora , 2019). Thus, the objectives of this study were (1) to determine the extent to which the current aspects of idarah, imarah and ri'ayah were applied to BKM in Langsa City; (2) analyze what entrepreneurial practices are carried out by BKM BKM in Langsa City; (3) see to what extent the effectiveness of entrepreneurship management at BKM in Langsa City in terms of sharia.

\section{Reseach Methods}

This research is an exploratory research with a qualitative approach. The duration of the study is 2 months (July to September 2020). Samples were selected based on the division of regions, namely 1 Langsa Municipality and 5 Districts in the Langsa City area. Each district will determine one mosque prosperity body which will be used as the object of research. The $\mathrm{BKM}$ consists of $1 \mathrm{BKM}$ for Langsa Municipality and $5 \mathrm{BKM}$ for sub-districts. Where the 
BKM-BKM is for Langsa Municipality there is BKM Darul Falah (DF) and for Langsa Barat with BKM Baitul Aminin (BA), East Langsa with BKM Nurul Quran (NQ), Langsa Kota with BKM Taqwa (TW), Langsa Lama with BKM Nurul Iman (NI) and Langsa Baro with BKM Baitul Mukmin (BM). The stages of the research method began with observation, identification, and literature review, data collection, designing research instruments, Focus Group Discussion (FGD), data analysis and discussion of research results.

In this study, the data collection methods used were interviews and documentation. Moleong (2008) states that an interview is a conversation with a specific purpose carried out by two parties, namely the interviewer who asks the question and the interviewee who provides answers to these questions related to this research. Before conducting the interview, the author first compiles a list of questions that will be asked to informants so that they are structured in such a way.

Documentation, on the other hand, according to Sugiyono (2012) is a record of events that have passed. In this study, the form of documentation in question is some data and experiences that BKM management has gone through during their stewardship period and some relevant data that can be used as support for this research. Among these are the regulations of the Director General of the Ministry of Religion. Brochures, BKM reports and Decree on the Appointment of BKM administrators that are considered important as well as other photo documentation.

Determination of informants using purposive sampling technique which means selecting research subjects and research locations with the aim of studying or understanding the main problems to be studied (Herdiansyah, 2009). The informants in this study were BKM in Langsa City. Informants are taken using the snowball sampling method, because the phenomenon under study can develop into a deeper and wider area than previously determined so that it is adjusted to the data needs that have been obtained. This method is used in order to obtain accurate and in-depth data regarding the existing conditions and problems. Several tools were used as a medium for data collection through interviews. Among them are in the form of notebooks, tape recorders and cameras (Sugiono, 2014: 395). Other data collection techniques are documenting data in the form of government regulation data, Islamic sharia service regulations, treatises and some supporting data that are considered relevant to this research. According to Bogdan in Sugiono (2014), in most traditions of qualitative research, the phrase persoanl document is used broadly to refer to any first person narrative produced by individual who describes his or her own actions, experience and belief. Then the collected data will be processed by synchronizing the results of the interviews with some supporting data in the form of research documentation. Then after the data from the field notes are obtained, it is necessary to make data coding and categorization. This data was then confirmed in a focus group discussion (FGD) in which all BKM heads and deputy administrators who were informants were invited together in the FGD activity. Merton in Moleong (2006: 228). Focused interviews with groups of people lead to a variety of answers and generate broader ground. With the synchronized data, data analysis was then carried out. The data analysis was carried out using the hermeneutic mode in which this approach emphasizes an analogue text consisting of verbal understanding and analogous discussion of data from focus group interviews. 


\section{Discussion}

In this study, the results obtained in the form of data that are categorized based on sharia reviews according to each BKM that have been observed and interviewed based on functions such as Idarah, Imarah and Ri'ayah.

Table 1. BKM Entrepreneurship Management in Langsa City in terms of Sharia

\begin{tabular}{|c|c|c|c|c|c|c|c|}
\hline No & Description & \multicolumn{6}{|c|}{ BKM } \\
\hline 1 & 2 & 3 & 4 & 5 & 6 & 7 & 8 \\
\hline & $\begin{array}{l}\text { Standardization of mosque } \\
\text { coaching }\end{array}$ & $\begin{array}{l}\text { Darul } \\
\text { Falah }\end{array}$ & $\begin{array}{l}\text { Nurul } \\
\text { Quran }\end{array}$ & $\begin{array}{l}\text { Nurul } \\
\text { Iman }\end{array}$ & $\begin{array}{l}\text { Baitul } \\
\text { Mukmin }\end{array}$ & $\begin{array}{l}\text { Baitul } \\
\text { Aminin }\end{array}$ & Taqwa \\
\hline & $\begin{array}{l}\text { domicile: } \\
\text { City / District }\end{array}$ & $\begin{array}{l}\text { Langsa } \\
\text { City }\end{array}$ & $\begin{array}{c}\text { Langsa } \\
\text { Timur }\end{array}$ & $\begin{array}{l}\text { Langsa } \\
\text { Lama }\end{array}$ & $\begin{array}{c}\text { Langsa } \\
\text { Baro }\end{array}$ & $\begin{array}{c}\text { Langsa } \\
\text { Barat }\end{array}$ & $\begin{array}{l}\text { Langsa } \\
\text { City }\end{array}$ \\
\hline & Mosque Status & Agung & Big & Big & Big & Big & Prganisasi \\
\hline $\mathrm{I}$ & Idarah Standard & & & & & & \\
\hline 1 & SK. Management & there is & there is & there is & there is & there is & there is \\
\hline 2 & Sources of funding & there is & there is & there is & there is & there is & there is \\
\hline 3 & Job descriptions & there is & - & - & - & - & - \\
\hline 4 & Accountable office admin system & there is & - & - & Ada & - & - \\
\hline 5 & $\begin{array}{l}\text { Management of building } \\
\text { management }\end{array}$ & there is & there is & there is & there is & there is & there is \\
\hline 6 & Has a high priest \& Muadzin & there is & there is & there is & there is & there is & there is \\
\hline 7 & Become a reference for the ideal mosque & there is & there is & there is & there is & there is & there is \\
\hline II & Imarah Standard & & & & & & \\
\hline 1 & $\begin{array}{l}\text { Organizing fardu / Friday / Islamic } \\
\text { holidays }\end{array}$ & there is & there is & there is & there is & there is & there is \\
\hline 2 & $\begin{array}{l}\text { Has an administrative system / } \\
\text { Islamic bank / shop / hall / lodging / } \\
\text { clinic / school }\end{array}$ & - & - & - & - & - & - \\
\hline 3 & $\begin{array}{l}\text { Organizing social \& economic } \\
\text { empowerment (zakat institutions / } \\
\text { BMT / Islamic banks / cooperatives } \\
\text { / ATMs }\end{array}$ & there is & - & - & - & - & - \\
\hline 4 & $\begin{array}{l}\text { Organizing youth development / } \\
\text { youth in mosques }\end{array}$ & there is & there is & there is & - & there is & there is \\
\hline 5 & $\begin{array}{l}\text { Organizing Hajj / Umrah ritual } \\
\text { guidance }\end{array}$ & there is & - & - & - & - & - \\
\hline 6 & $\begin{array}{l}\text { Carrying out health services / } \\
\text { monitoring the bodies }\end{array}$ & - & - & - & - & - & - \\
\hline 7 & Carrying out Islamic studies & there is & there is & there is & there is & there is & there is \\
\hline III & Ri'ayah Standard & & & & & & \\
\hline 1 & $\begin{array}{l}\text { There is a prayer room for } 8,000 \\
\text { worshipers }\end{array}$ & there is & - & - & - & - & - \\
\hline 2 & $\begin{array}{l}\text { There are } 50 \text { units of prayer } \\
\text { equipment for women / mukena and } \\
\text { a place to store them }\end{array}$ & there is & - & - & - & - & - \\
\hline 3 & There is a VIP living room & there is & there is & - & there is & there is & there is \\
\hline 4 & Available hall / function room & there is & - & - & - & - & there is \\
\hline 5 & $\begin{array}{l}\text { There are separate ablution places } \\
\text { for men \& women }\end{array}$ & there is & there is & there is & there is & there is & there is \\
\hline 6 & There is a sound system & there is & there is & there is & there is & there is & there is \\
\hline 7 & $\begin{array}{l}\text { There is a room for the Imam and } \\
\text { muadzin / roar for consultation / } \\
\text { BKM secretariat }\end{array}$ & there is & there is & there is & there is & there is & there is \\
\hline
\end{tabular}

Source: BKM Langsa City (data processed, 2020) 
The table above is the result of research that has been processed into data which is confirmed by existing sources in each BKM-BKM who have been previously observed. The BKM management assessment format above is adjusted to the Decree of the Director General of Islamic Community Guidance Number DJ.II / 802 of 2014 concerning Mosque Management Guidance Standards. Where the BKM assessment is viewed from three sharia functions, namely the function of idarah, imarah and ri'ayah, each of which is based on 7 standard criteria (contained in the items in table III-1). Based on the data contained in the table above, it can be explained where for the Great Mosque located in Langsa Municipality which is managed by BKM Darul Falah shows that from the aspects of idarah, imarah and ri'ayah the majority have met the criteria (except for entrepreneurial / sharia economic standards. which has not been handled properly). Meanwhile, the BKM Kecamatan which consists of BKM Nurul Quran, BKM Nurul Iman, BKM Baitul Mukmin, BKM Baitul Aminin (status of a large mosque) and BKM Taqwa (organization mosque) are found to have not been well managed or have not met the criteria of predetermined standards. the. In other words, only meeting the minimum standards is like focusing on worship activities related to Friday and Friday prayers. Meanwhile, in terms of entrepreneurial prosperity, activities cannot be carried out, of course, with various considerations.

In practice, the implementation of mosque management by BKM in Langsa City refers to the assessment criteria in this research as follows:

1. The research results were obtained by conducting interviews with the chairman of BKM Darul Falah (BKM DF) and several other administrators. Some of the research questions that need to be answered are as follows:

2. How do the aspects of idarah, imarah and ri'ayah be applied to the Darul Falah BKM?

"BKM DF First I convey about the problem of the Great Mosque of Darul Falah Langsa City. The management of the Great Mosque of Darul Falah, Langsa City is stipulated by the Decree of the Mayor of Langsa, then in the management there are 3 (three) fields, namely; The Emirate which regulates matters of prosperity, the second Idarah which regulates matters of operational matters, and the third is Ri'ayah which regulates development issues. So regarding the problems of each of these fields, it has been regulated in a regulation of the Minister of Religion, regarding the work in accordance with their respective fields. The Idarah sector concerns operational matters in accordance with the guidelines for the regulations of the Minister of Religion."

Then the field of prosperity, of course, collects problems of data management, time and so on such as prayer times, regulating preachers, recitations including the Taqlim Council, these are regulated in the field of the Imarah.

3. How is the application of the aspects of idarah, imarah and ri'ayah at BKM at the Kecamatan Mosque? (BKM NQ; BKM NI; BKM BM; BKM BA; BKM TW):

"BKM NI / NQ / BM / BA / TW from the idarah function, a new management letter received from the village head (Geuchik) while BKM TW has been issued for several years. BKM funding sources are still focused on donations by the congregation only by simple manual recording. Likewise, the administrative system still implements a simple system because it does not have a clear job description. Watch the case with building management where the BKM has formed a separate management with the aim of making development more focused. For the existence of a great faith and muezzin for all mosques there is because the decree of the appointment was directly issued by the Gampong Geuhik himself." 
"From the function of imarah (prosperity) they have carried out well in the form of implementing aspects of education and organizing Islamic studies. However, the case is different, especially in the aspects of the business administration system (Islamic banks / shops / aual / lodging / clinics / schools and aspects of social and economic empowerment (zakat institutions / BMT / Islamic banks / cooperatives / ATMs) where all BKMs do not have data about it. Similar to the aspects of the implementation of the Hajj / Umrah rituals and health services / distribution of bodies, the BKM management does not yet have this program."

"For the ri'ayah function, facilities for separate wudhuk places for men and women, sound system facilities and the completeness of the priest and muezzin rooms, consultation rooms and the BKM secretariat are owned by all BKMs in this sub-district. Meanwhile, the capacity of the prayer room which accommodates 8,000 people, as well as the completeness of the women's prayer room in the number of 50 units and the storage area is not yet complete. Likewise with the support of multipurpose hall which BKM is not ready to provide. In addition, for the provision of VIP guest rooms, only four BKMs have it, while BKM NI has not."

4. How are entrepreneurial practices carried out by BKM BKM in Langsa City?

The understanding and practice of entrepreneurship at BKM Darul Falah Langsa is as the result of the following interview:

"BKM DF "regarding the field of entrepreneurship at the Great Mosque of Darul Falah, Langsa City, for now, his own business exists, in the area of the mosque, namely rental for kiosks and supervised by Idarah as an operational sector, but citing the money problem is the general treasurer. The section on the welfare sector of the mosque or the section of worship, especially in the field of the Imarah, including such as, TPA, recitation, which is a syiar included in the prosperity of the Imarah sector."

5. How to understand and practice entrepreneurship at BKM in the District Mosque (BKM NQ; BKM NI; BKM BM; BKM BA; BKM TW):

"BKM NI "Previously we also had businesses such as renting sound for weddings and other events, but now we have lost to kibot and so on so that it only lasts a few seasons with a rental price of IDR. 200,000 ". The business is no longer running as well as insufficient capital to finance the business."

"BKM NQ / BM / BA / TW from the four BKMs they quite understand that entrepreneurship management has a good opportunity, but today we can only plan it due to the lack of funds in the BKM treasury that we currently manage. We hope that in the future there will be parties who help both in terms of capital and assistance in the form of entrepreneurship training."

6. To what extent is the effectiveness of entrepreneurship management at BKM in Langsa City in terms of sharia?

"To obtain data that supports this research, the research team carried out a focus group discussion (FGD) by inviting all chairmen and representatives of BKM who were the objects of this research by inviting expert sources including the Head of the Langsa City Islamic Sharia Service, who was held by Mr. Aji Asmanuddin. , S.Ag., MA, expert on muamalah / sharia economics from the Postgraduate Program at IAIN Langsa, namely Dr. H. Zulkarnaini, MA and the Advisor of the Sharia Economic Community (MES) of Langsa City, namely Dr. Zulkarnain, MA." 
Expert resource 1: Mr. Aji Asmanuddin, S.Ag., MA explained that the Quba Mosque was first established by the Prophet. Rasulullah continued to develop the mosque all the way to Medina. As an apostle as well as the head of government at that time, he continued to make regulations in the management of mosques. Then the Prophet developed a mosque with various functions. In addition, there are 11 mosques that function as:

1. The place of worship for rawative prayers, Friday prayers, taraweh prayers etc.,

2. A place to study

3. Dormitory

4. The place to give fatwas to the public

5. A place to receive guests

6. The place of marriage (in accordance with the Qanun),

In Aceh, starting from Subussalam to Aceh Tamiang the marriage process has been returned to the mosque while the quack is only as a place for administration / management)

7. Community social place (this relates to this research too)

8. Equestrian war training ground

9. Medical and health services (as the center of all community activities during the time of the Prophet)

10. Rest / dormitory

11. Place for prisoners of war for the polytheists

At that time everything was complex at the time of the Apostle. According to the Decree of the Minister of Religion (KMA) number 802/2014, the mosque is further divided into bkm. In Java the name is DKM, whose goal is to truly prosper the congregation to the community, which in the end is money for the community. Meanwhile, in Aceh it is only BKM that only makes mosques prosper. For example in Yogyakarta, there is a Jogokaryan mosque, the balance is never a million and the balance is still 0 because the entire fund is used for the prosperity of the mosque alone

Speaker 2: Dr. Zulkarnaini, MA explained about the role of BKM in advancing the welfare of the people from the sharia side by making the entrepreneurial management of mosques important, and there are most of us who consider entrepreneurship as something trivial. The behavior of the Acehnese in consuming has a less calculating mentality. This means criticism. And this has a profound impact on prosperity in the financial context of everyone wanting prosperity. If a mosque has a body that is strong enough to change the mentality of youth and Acehnese society by increasing the entrepreneurial spirit through providing training and guidance to deepen entrepreneurial knowledge, the mosque will be a very powerful force to build. According to the welfare theory by the philosopher Angel, when giving speeches by humans before stepping into religious philosophy, politics and so on, they need to eat, this is a simple theory meaning that if we are able to make a prosperous society, it is easy to increase the spirit to prosper the mosque. This is an important step to streamline entrepreneurial management which is one of the ways or alternatives that need to be taken by the mosque / BKM management.

Expert resource 3: Dr. Zulkarnain, MA, as the mentor of MES Kota Langsa, explained that mosques are seen as resources that have potential, especially in the welfare of the people, of course, through socio-economics. The mosque is seen from two sides, namely the isotherm side (inside), which is to see things related to its spiritual activities and the exothermic side (outside), namely efforts to improve all things outside of spirituality including its economic development. 
The Prophet said:

"Man Banna Masjidan Fiddunya Bannallahu Baitan Fil Jannah"

Meaning: whoever builds a mosque in the world, Allah will build his house in Heaven.Banna includes the economic side, when building the building it also needs to build economic strength, military, health and so on.

The Prophet wanted the meaning of building a mosque to build in a holistic sense, including building economy, politics, and health and so on. The Prophet did all things in the mosque. Mosques are seen as centers of civilization that can increase dignity and dignity. The mosque cash which is managed by BKM must be divided according to commercial and noncommercial business financing. So there is no BKM mosque that does not carry out commercial and non-commercial financing. It was from the funds of the people in the mosque that people tried to avoid the prophet's worries.

The next concept is:

Yadul ulya kairummina yadul sufla

Meaning: the hand above is more mulya than the hand above.

So if the economic concept adopted by BKM is alive, the ummah will increase because they have given rather than received. Even though the next step of the Ummah should be avoided first from poverty. There is a big BKM step towards the welfare of the people based on the mosque. Some samples from several mosques that have carried out real mosque-based activities include:

1. Hajj and Umrah stalls controlled by BKM in Manado

2. Sacrificial animal fattening services, for qurban holidays and within six months they get a profit of three to five million at Masjid Raya Bima, NTB

3. Stalls equipped with fardu kifayah in several BKM mosques in Madura, and can employ congregations.

4. Rice ATMs, several BKM in Jember

5. Ambulance service, with a rather large capital (half of the village fund and half of the mosque fund) and the cost is cheaper because of its social value

6. Sharia and hygienic cut chicken services how to cut chicken according to sharia and the water is clean and becomes a big incom

7. Friday snack stalls around mosques (such as mosques in Langkat)

8. The mosque is managed by an Islamic association, (Parsis) selling gold dowry / wedding jewelry at outlets around the mosque.

Referring to the results of research obtained where the practice of entrepreneurship that exists in each BKM-BKM in Langsa City, if viewed from table III-1, it can be stated that it has not been seen clearly about the routine that has emerged. So it can be said that the implementation has not been effective. Considering this can be caused by several things, including the characteristics of the management who do not understand correctly how to operationalize entrepreneurial practices in BKM. Then almost all BKMs admit that capital is the basic reason for the application of entrepreneurial practices in BKM. Furthermore, inadequate expertise / skills with regard to the use of facilities and facilities owned by BKM to run sharia-based business businesses. Finally, the partnership which is a milestone for building a business at BKM-BKM in Langsa City has not been developed. By itself, this is all that makes BKM become a waste and stay in place. This is in accordance with the Word of God in Surah An-Nur verse 37 which reads: 


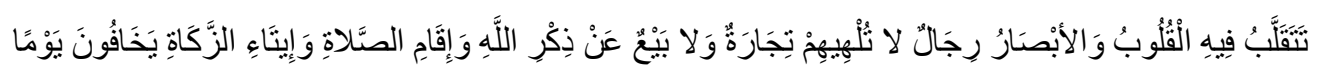

Meaning:"Men who are not neglected by commerce and not (also) by buying and selling from remembering Allah, and (from) establishing prayers, and (from) paying zakat. They are afraid of one day (on that day) their hearts and eyesight will be shaken ".

Thus, to create the same perception, it is necessary to form an entrepreneurial management model in BKM Langsa City. Based on this model, it will make it easier for all BKM administrators to plan, utilize resources, manage potential assets and monitor and evaluate BKM's entrepreneurial journey in Langsa City with the ultimate goal of prosperity for the congregation as a whole. The following is the entrepreneurial management model at BKM in Langsa City in terms of sharia.

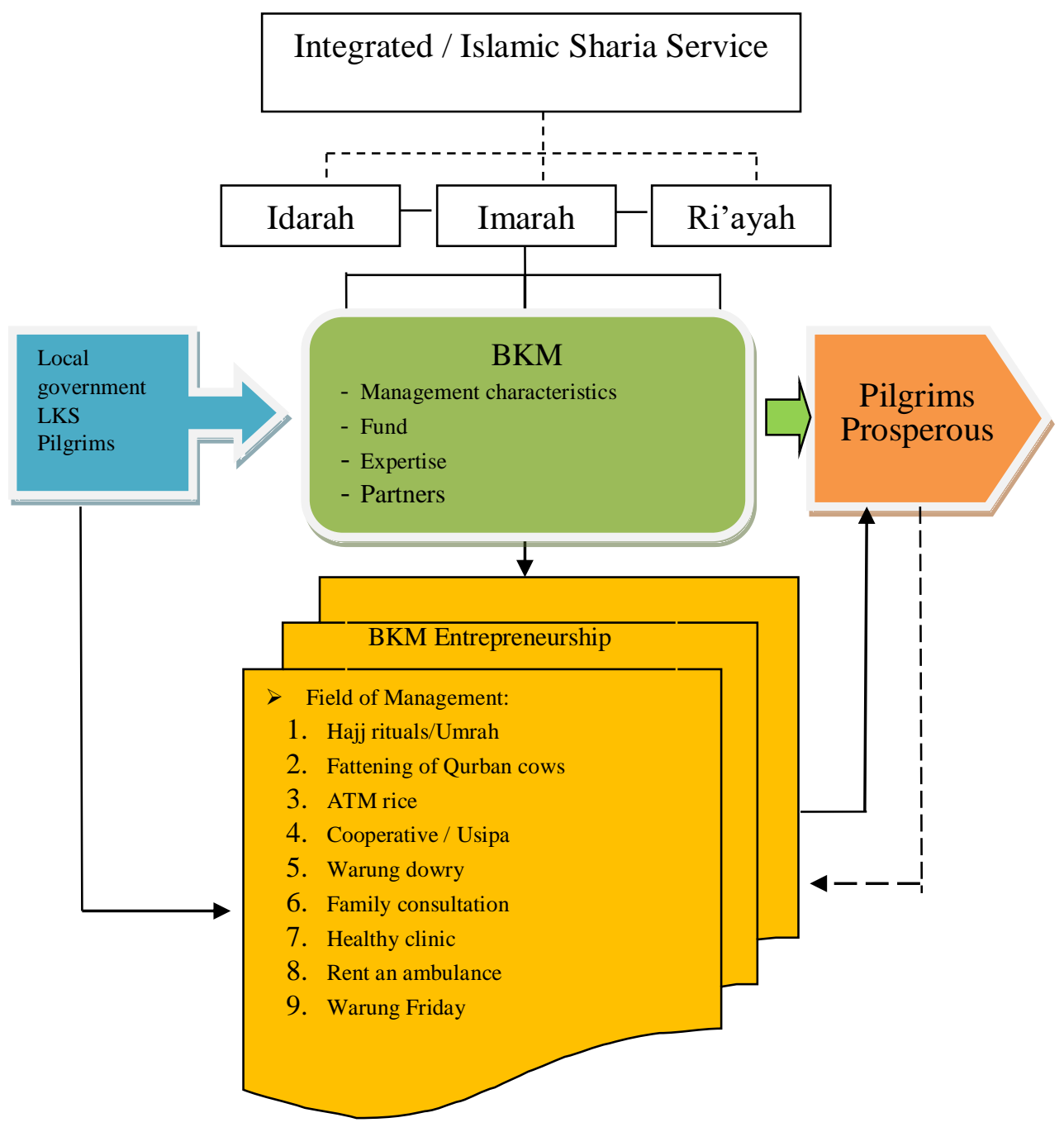

Figure 1. BKM Entrepreneurship Management Model

In the model above, it explains to us that the source of funds can be obtained from the government and local governments, Islamic financial institutions and congregations that are deposited to BKM with characteristics that must have entrepreneurial characteristics, expertise and can open opportunities for cooperation with partners. Then the funding sources obtained by BKM can be allocated to various forms of business such as Hajj or Umrah rituals, raising cows for qurban, utilizing rice ATMs in the form of cooperation with local 
village farmers to be sold to congregations, being able to build cooperative savings and loan units, opening dowry stalls for those who want to get married, provide family consultations (pre-wedding or family), health clinics, ambulance services and even food stalls on the eve of Friday prayers around the mosque. Furthermore, the results of the business undertaken by BKM can be distributed to the congregation in goods or services towards the prosperity of the people. In addition, if there are congregants who are still lacking, especially in entrepreneurship, then an entrepreneurial education is needed from related agencies, especially the Islamic Sharia Service so that the congregation is able from an economic standpoint (Syardiansah, 2019; Haryati, et al, 2019) Thus BKM can empower these people. to be employed in certain business fields according to the productivity they produce. Productivity is the relationship between the results obtained and the resources used to produce both products and services (Mora, et al., 2020; Syardiansah, 2020). Thus, a strong effort is needed to encourage the formation of interest and motivation from BKM administrators in Langsa City to realize the success of entrepreneurial management in order to form a more effective competitiveness (Aji Asmanuddin, Kadis Syariat Islam Kota Langsa, FGD: 2020).

\section{Conclusion}

BKM's ability to manage entrepreneurship management is highly dependent on the characteristics of the management and the assets and partners they have. Today BKM in Langsa City has the potential to develop especially when they are able to build the community's economy through entrepreneurial management with the full support of the government, in this case the Langsa City Islamic Sharia Service which is based on improving the quality of the Idarah function, the Imarah function and the ri'ayah function with institutional supervision related institutions. The congregation is hope. BKM is a medium for achieving the values of prosperity so that the congregation can be free from kufr western capitalism. Although we know that the existing BKM BKM is not yet effective in carrying out entrepreneurial management in the city of Langsa, however by utilizing aspects of sharia aspects such as idarah, imarah and ri'ayah, all BKM in Langsa city will advance in improving the standard of living of the congregation and the city community langsa civilian.

\section{References}

Abdullah, Mulat Wigati, (2006), Sosiologi. Jakarta: Grasindo

Al kaaf, Abdullah Z. (2017). Ekonomi Dalam Perspektif Islam. Bandung: Pustaka Setia

Alamsyah, Halim. (2012). Perkembangan dan Prospek Perbankan Syariah Indonesia: Tantangan Dalam Menyongsong MEA 2015. Paper dipresentasikan pada Milad ke-8 Ikatan Ahli Ekonomi Islam (IAEI), 13 April, Jakarta

Ardianti. D. A dan Mora. Z.(2019). Pengaruh Miat Usaha Dan Motivasi Usaha Terhadap Keberhasilan Usaha Wirausaha Muda di Kota Langsa. Jurnal Samudra Ekonomi Dan Bisnis. Volume 10. Nomor 2

Asmanuddin, Aji., Zulkarnaini dan Zulkarnain. (2020). Focuss Group Discussion. Penelitian Dasar Unggulan. Langsa: LPPM \& PM Universitas Samudra

Bahri, (2018). Kewirausahaan Islam: Penerapan Konsep Berwirausaha dan Bertransaksi Syariah dengan Metode Dimensi Vertikal (Hablumminallah) dan Dimensi Horizontal (Habluminallah), Jurnal Ekonomi Syariah dan Bisnis, Volume 1, Nomor 2

Budiman, Mohammad Arif dan Mairijani. (2016). Peran Masjid dalam Pengembangan Ekonomi Syariah di kota Banjarmasin. Jurnal Studi Ekonomi, Volume 7, Nomor 2 
Dalmeri, (2014). Revitalisasi Fungsi Masjid sebagai Pusat Ekonomi dan Dakwah Multikultural. Walisongo, Volume 22, Nomor 2.

Dahlan,et al. 2015. Developing Islamic City through Network-of-Mosque (NoM). Proceedings of 4 International Conference on Management, Finance \& Entrepreneurship (ICMFE-2015)

Haryati, Endang., Suharyanto, Agung., Hasmayni, Baby. \& Siregar, Farida Hanum. (2019). The Effect of Work Environment and Work Stress on Employee Performance at PT Aneka Gas Industri Tbk, Research Article in Proceedings of the 2nd International Conference on Social Sciences and Interdisciplinary Studies (formerly ICCSSIS), ICCSIS 2019, 24-25 October 2019, Medan, North Sumatera, Indonesia

Helmi,.et al.(2019). Implementation Place of 'Uqubat Canings in Fiqh Perspective (Analysis of Aceh Governor Regulation Number 5 of 2018). Budapest International Research and Critics Institute-Journal (BIRCI-Journal). P. 65-73

Kementerian Agama RI. (2014). Keputusan Direktur Jendral Bimbingan Masyarakat Islam Nomor DJ.II/802 Tahun 2014 tentang Standar Pembinaan Manajemen Masjid. Jakarta: kementerian Agama Republik Indonesia

Lendechy, H. et al. (2019). Rural Women Who Undertake and Empower Themselves: Comparative Analysis in Communities in Mexico. Budapest International Research and Critics Institute-Journal (BIRCI-Journal).P. 20-30

Moleong, Lexy, J. (2006). Metode Penelitian Kualitatif, Ed. Revisi. Bandung: Remaja Rosdakarya

Mora, Zulkarnen., Suharyanto, Agung., Yahya, M. (2020). Efect Of Work Safett And Healty Towards Employee's Productivity in PT. Sisirau Aceh Tamiang. Budapest International Research and Critics Institute, 3(2): 753-760.

Syardiansah. (2019). Pengaruh Minat dan Pendidikan Kewirausahaan terhadap Motivasi Berwirausaha. JUPIIS: Jurnal Pendidikan Ilmuilmu Sosial, 11 (2):183-192

Syardiansah, Latief, Abdul., Daud, Muhammad Nur., Windi, \& Suharyanto, Agung. (2020). The Effect of Job Satisfaction and Organizational Culture on Employee Performance of the Royal Hotel in East Aceh District, Budapest International Research and Critics Institute, 3(2): 849-857.

Sugiyono. (2014). Metode Penelitian Manajemen. Bandung: Alfabeta

Supriyadi, Ahmad. (2017). Pemberdayaan Ekonomi Berbasis Masjid. AN-NISBAH, Vol. 03, No. 02

Praswati, Aflit Nuryulia. (2017). Perkembangan Model Helix dalam Peningkatan Inovasi. Prosiding Seminar Nasional Riset Manajemen \& Bisnis (Perkembangan Konsep dan Riset E-Business di Indonesia)

Yani, Ahmad., (2009), Panduan Memakmurkan Masjid, Jakarta: Al Qalam

http://dsi.acehprov.go.id/wp-content/uploads/2017/02/Qanun-Aceh-Nomor-9-Tahun-2008-

Tentang-Pembinaan-Kehidupan-Adat-dan-Adat-Istiadat.pdf diakses pada 14 Juni 2018 http://simas.kemenag.go.id/index.php/home/ diakses pda 17 Juni 2018

https://muizzaattaj.wordpress.com/2016/05/23/entrepreneurship-dalam-alquran-dan-hadits/ https://muizzaattaj.wordpress.com/2016/05/23/entrepreneurship-dalam-alquran-dan-hadits/ 